\title{
Impact of CEO Duality and Audit Committee on Firm Performance: A Study of Oil \& Gas Listed Firms of Pakistan
}

\author{
Muhammad $\operatorname{Arslan}^{1}$ (Corresponding Author) \\ M.Phil (MS) \\ Bahria University Islamabad, Pakistan \\ Tel: +923317500173 Email: MuhammadArslan73@gmail.com \\ Rashid Zaman ${ }^{2}$ \\ M.Phil (MS) \\ Bahria University Islamabad, Pakistan \\ Dr R.K.Malik \\ Head of Campus
}

Shaheed Zulfiqar Ali Bhutto Institute of Science and Technology, Islamabad, Pakistan

Asif Mehmood ${ }^{4}$

MBA

Allama Iqbal Open University, Islamabad

\begin{abstract}
This paper examines the relationship between corporate governance mechanisms and performance of the firm. In this empirical paper, audit committee and CEO duality are taken as corporate governance mechanisms and profit margin and return on equity are taken as a measure of performance of the firm for a sample of 11 listed firms of Pakistan for year 2010-2011. Results reveal positive significant relationship of return on equity and profit margin with audit committee. However, this study could not provide a significant relationship of CEO duality with return on equity and profit of the firm. The findings of study help policy makers in setting of proper policies. The finding also determines the importance of audit committee and CEO duality in terms of profitability.
\end{abstract}

Keywords: Corporate Governance, Firm Performance, CEO Duality

\section{Introduction}

Corporate governance has generated positive returns for the firm because they also boost confidence in firms. Corporate governance best practices have different dimensions. These dimensions have significant effect on firm performance. In this Paper, the CEO/Chairman duality and audit committee both are taken as independent variables because they have significant impact on the firm performance. There are a lot of ways to check the firm performance like EPS, Debt to equity ratio, Profit margin, dividend etc. In this Paper the return on equity and net profit margin are taken as indicator of firm performance. This paper examined the impact of CEO duality and independent audit committee on return on equity and net profit margin of the firm. In previous studies there were used variables like board size, board composition, CEO duality etc but in those studies the EPS and profit margin were taken as dependent variables. In previous these types of paper were conducted by taking sample of cement listed and KSE-30 index. But in this paper oil and gas companies which were listed on KSE were taken as sample firms. There were 12 firms listed on KSE but in this paper only 11 firms were selected. It was $91 \%$ of total population. In this paper there were used 2010 and 2011 data. This data were collected from annual reports of these firms. Section 2 deals with literature review. Section 3 deals with methodology and model specification. Ordinary least square method is used for determining the results. Section 4 deals with results and discussions. Next section deals conclusion.

\section{Literature Review}

In Pakistan, the literature regarding corporate governance is thin and it is due to lack of research culture in Pakistani institutional and academic areas. There is much more literature on India than among the other South Asian countries (Goswami, 2002; Khanna M \& D, 1999; Khanna M, Wilma RQ, \& Dora, 1998; Pankaj, 1996; Singh A, Singh A, \& B, 2002). Researcher sums up the growth history of corporations in Pakistan and also provides overviews about the state of financial markets, ownership structure and the changing market Cheema, at, el. (2003). Many researchers observed the ownership and control concentration to determine the capital market and ownership structure of Pakistan (Cho, 1998; Demsetz \& Villalonga, 2001).

\section{Corporate Governance and Firm Performance}

There are numerous studies that have investigated the connection between the corporate governance and the firm performance and their results are mixed (Anderson, Mansi, \& Reeb, 2004; Black BS, Tang H, \& Kim 
W, 2003; Gompers, Ishii, \& Metrick, 2003; Klappe \& Inessa). The researchers also argued that interest rate has significant positive impact on performance of firm. (Zaman, et al., 2014). In previous literature some researcher concluded that there is systematic relationship between the characteristics of board but its evidence is little (Adenikinju \& Ayorinde, 2001). But some researchers determined the positive \& some found negative relationship between firm performance and corporate governance (Bhagat \& Black, 2002).

Incorporation the audit committee's work as link between external, internal auditor and also between the board of directors ("Finance Committee on Corporate Governance," 1999). Audit committee assist the auditors rather than management and resolves the disputes between the management and auditors (Abbott \& Parker, 2000). Audit committee is only most important board of directors subcommittee due to its role of protecting the interest of shareholders and financial control (Mallin, 2007). It was found in literature that if the financial reports are disclosed in better quality then performance of firm improves (Wild, 1996). In US, the audit committee is required to review and discuss the firm's risk assessment and strategies for hedging of risk ("NYSE,"). The revised Code of Corporate Governance (2012) issued by Securities and Exchange Commission of Pakistan describes the following benchmarks for international best practices SECP (2012).

\section{Audit Committee}

The Chairman of the audit committee shall be an independent director, who shall not be the chairman of the board. Audit Committee shall comprise of non-executive directors. The secretary of Audit Committee shall either be the Company Secretary or Head of Internal Audit. However, the CFO shall not be appointed as the secretary to the Audit Committee. Human Resources and Remuneration Committee introduced by SECP (2012). The internal audit function may be outsourced by a listed company to a professional services firm or be performed by the internal audit staff of the holding company. In the event of outsourcing the internal audit function, the company shall appoint or designate a fulltime employee other than the CFO, as Head of Internal Audit, to act as coordinator between the firm providing internal audit services and the board by SECP (2012). Audit committee determines the appropriate measures to safeguards company's assets; review the preliminary announcements of results prior to publication; review the quarterly and annual financial statements of the Company, prior to their approval by the board of directors and facilitating external auditors and coordinating internal and external auditors by SECP (2012).

\section{Corporate Governance Mechanisms}

There are many dynamics or variables that may constitute benchmarks by which corporate governance can be measured in an organization. Some of these mechanisms are briefly discussed following.

\section{CEO/Chairman Duality}

In literature there is enormous critique on CEO duality. By keep in mind the agency theory there are different arguments some researchers says that CEO duality diminish the monitoring role of board of directors. On the other hand, the stewardship theory stresses that a unity of command of a CEO leads to an unambiguous leadership over subordinates to this. Due to this induces the effective decision making (Donaldson \& Davis, 1991). In this paper CEO/Chairman duality is taken as independent variable. There are enormous studies in which corporate governance practices dimensions like board size, board composition, CEO duality and audit committee were taken as independent variables (Anderson, et al., 2004; Mallin, 2007). In those studies researchers examined the impact of these variables on firm performance but they take EPS, debt to equity ratio and Tobin's Q as indicator of firm performance Arshad, et al. (2011). Researchers also studied that unemployment increased due to poor firm performance (Arslan \& Zaman, 2014).

Some researcher suggest that there is no optimal leadership structure because duality and separation both have related benefits and costs (James, a, \& Gregg, 1997). CEO duality causes information problems as he determines the agenda and information to the board (Jensen, 1993). CEO duality has also been linked to other signs of ineffective governance, such as in the cases of antagonistic takeovers (Morck, Shleifer, \& Vishny, 1988). In some researches the researchers have focused on the audit committee and they take profit margin as a measure of performance of firm (Yasser, Entebang, \& Mansor, 2011).

\section{Audit Committee}

In literature, some authors reported negative correlation between independence of audit committee and earning management (Klein, 1998). Some researcher found that audit committee has positive and significant impact on performance of the firm (Klein A, 1998; Roe M, 2002). According to some researchers it was found that cost of debt financing can be lowered if there is entirely independent audit committee Anderson,et.al (2004). In literature there were enormous studies in corporate governance practices Arshad, et al. (2011). In some researches it was found that audit committee has positive and significant impact on profit margin and return on equity of the firm (Yasser, et al., 2011). 


\section{Return on Equity}

In previous literature there were positive relationship between the corporate governance practices and return on equity (Shaheen \& Nishat, 2004). In previous literature it was found that independent audit committee has positive impact on return on equity (Shaheen \& Nishat, 2004). In previous studies the relationship of CEO and return on equity is weak (Yasser, et al., 2011).

\section{Profit Margin}

In literature it is found that independent audit committee has no impact on net profit of the firm (Shaheen \& Nishat, 2004). But in some researches it was found that independent audit committee has strong positive significant impact on profit margin of the firm (Klein A, 1998; Muhammad Aves Arshad, et al., 2011; Roe M, 2002; Yasser, et al., 2011). It is also found that good corporate governance has positively related with net profit margin of the firm (Shaheen \& Nishat, 2004). In some researches there were found no relationship of net profit margin with corporate governance best practices (Bhagat \& Black, 2002).

Theoretical Framework

\section{Independent Variables \\ Corporate Governance Practices \\ - CEO Duality \\ - Audit Committee}

\section{Dependent Variables}

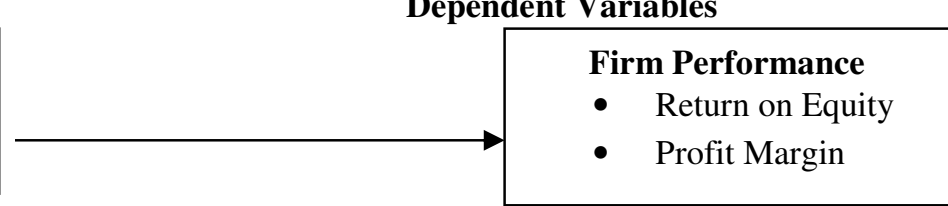

Adapt from (Muhammad Aves Arshad, et al., 2011)

\section{Variables Description}

In this paper the $\mathrm{CEO} / \mathrm{Chairman}$ duality and audit committee are taken as independent variables. The value zero if the CEO and chairman are same and value 1 if CEO and chairman are different head.

If the firm has audit committee consisting of non executive members who are independent then value 1 and if firm has no audit committee or if it doesn't consist of non executive members then value zero.

In this paper the firm performance is taken as dependent variable and it is determined by return on equity and profit margin of firm.

$$
\begin{aligned}
& \text { Return on Equity }=\frac{\text { Net profit generated during the year }}{\text { Average equity of firm at the year end }} \\
& \text { Profit margin }=\frac{\text { Net profit generaed during the year }}{\text { Total revenues of the firm }}
\end{aligned}
$$

\section{Hypothesis}

H1: CEO Duality has significant impact on return on equity of firm.

In previous studies many researchers argued that CEO duality and return on equity has significant weak relationship (Yasser, et al., 2011). The purpose of this study was to investigate this relationship.

H2: CEO Duality has significant impact on Profit Margin of firm.

The purpose of study was to determine relationship between profit margin and CEO. In previous researches it was argued that there is no relationship between CEO duality and profit margin of the firm (Yasser, et al., 2011).

H3: Audit Committee has significant impact on return on equity of firm.

Researchers argued that audit committee has strong significant effect on return on equity of the firm. Previous studies showed significant positive relationship between audit committee and return on equity of the firm (Muhammad Aves Arshad, et al., 2011; Yasser, et al., 2011).

H4: Audit Committee has significant impact on profit margin of firm.

In literature audit committee and profit margin of the firm had strong relationship with each other. This relationship were positive in nature (Muhammad Aves Arshad, et al., 2011; Yasser, et al., 2011).

\section{Methodology}

\section{Secondary Data}

Secondary data refer to information that is collected by individuals, agencies and institutions other than by the researcher Welman et.al.(2005). Secondary data is data which is collected for previous projects other than current project. In this paper the data were taken from the annual reports of the firms and the Karachi Stock Exchange was the authenticated source for annual reports of firms. In this paper there were used two years (i.e. 2010, 2011) data of these firms for getting authenticated results.

\section{Population}

Population presents the entire group of people, things or events that researcher wishes to investigate. In this 
paper the population was consisted of oil and gas companies in Pakistan which were listed on Karachi Stock Exchange. There were 12 companies listed on Karachi Stock Exchange. This industry was selected because it plays crucial rule in economy of Pakistan and these were adopted code of corporate governance effectively.

\section{Sample}

Sample is a subset of population and it should present the main objective of the study (Collis \& Hussey, 2003). In this paper the sample were consisted of 11 companies which was $91 \%$ of total population. These companies were Attock Petroleum, Attock Refinery Ltd, Byco Petroleum, Mari Gas Company, National Refinery, Oil \& Gas Development Company, Pak Oilfields, Pak Petroleum, Pak Refinery, P.S.O. and Shell Pakistan Ltd.

\section{Model Specification}

The economic model was used in the study is given below:

$Y=\beta^{\mathrm{o}}+\beta F_{\mathrm{i} t}+\mho_{\mathrm{i} \mathrm{t}}$

In above equation $\mathrm{Y}$ is the presenting the performance of firm and it is dependent variable. It is constant. $\beta$ is the coefficient of independent variables. $\mho_{i} t$, is the error term and it is assumed to have zero mean and independent across time period.

This paper employs two important ratios (return on equity and profit margin) to measure the performance of the firm in defined period of time.

By adopting the above economic model, the equation for this paper evolves:

Peformance $=\beta^{\mathrm{o}}+\beta_{1} C E O+\beta_{2}$ AuditCom $+\mho_{\mathrm{it}}$

\section{Results and Discussion}

\begin{tabular}{|c|c|c|c|c|}
\hline & ROE & $\mathbf{P M}$ & AUDCOM & CEO \\
\hline Mean & 0.04 & 0.11 & 0.91 & 0.73 \\
\hline Median & 0.28 & 0.02 & 1 & 1 \\
\hline Mode & - & 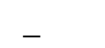 & 1 & 1 \\
\hline Std. Dev & 0.98 & 0.17 & 0.29 & 0.45 \\
\hline Skewness & -4.46 & 1.02 & -3.05 & -1.09 \\
\hline Kurtosis & 20.46 & -0.91 & 8.08 & -0.88 \\
\hline Range & 4.73 & 0.46 & 1 & 1 \\
\hline Minimum & -4.29 & -0.04 & 0 & 0 \\
\hline Maximum & 0.44 & 0.41 & 1 & 1 \\
\hline Sum & 0.91 & 2.56 & 20 & 16 \\
\hline $\mathbf{N}$ & 22 & 22 & 22 & 22 \\
\hline
\end{tabular}

Table 1 shows the descriptive statistics of firms. Results show that mean of ROE of sampled firms is 4 $\%$ and PM is $11 \%$. It means that on average, for every Rs. 100 turnover of sampled firms, Rs. 11 was the profit earned. Results indicate that $73 \%$ of sampled firms have separate persons occupying the position of CEO and board chairman. While $27 \%$ sample firms have same person having position of chairman and CEO. Only $9 \%$ of firms have audit committee consisting of executive members while $.91 \%$ of firms have audit committee composed by non executive members of the board and there are minimum three executive members in an audit committee of the firm.

Table 2 Correlation Matrix

\begin{tabular}{lr|r|r|r}
\hline & & \multicolumn{1}{l|}{ CEO } & Return on Equity \\
& Audit Committee & \multicolumn{1}{l|}{ Duality } & Profit Margin & 0.156501 \\
& 1 & -0.19365 & 0.181978 & 0.085421 \\
Audit Committee & -0.19365 & 1 & -0.06989 & 1 \\
CEO Duality & 0.181978 & -0.06989 & 0.255095 \\
Profit Margin & 0.156501 & 0.085421 & 0.255095 & 1 \\
Return on Equity & &
\end{tabular}

Table 2 results showed that there is positive and significant relationship between CEO duality and return on equity. These results have support from previous literature (Mansor,et.al.2011). CEO duality has significant but negative relationship with profit margin. It means it there is CEO duality then it has negative impact on profit margin of the firm. Results also show that audit committee has positive impact with return on equity and profit margin of the firm. This relationship is significant. These results are consistent with previous literature (Muhammad Aves Arshad, et al., 2011; Mansor,et.al.2011) 
Table 3a Regression: ROE as Dependent Variable

\begin{tabular}{lrcrr} 
Variable & Coefficient & Std. Error & t-Statistic & Prob. \\
\hline C & 65.36046 & 87.32021 & 0.748515 & 0.0433 \\
ACOM & 0.13717 & 76.83154 & -2.48121 & 0.0359 \\
CEO_DUALITY & 0.05248 & 49.59454 & -2.7647 & 0.0438 \\
R-squared & 0.095036 & Mean dependent var & & 0.168113 \\
Adjusted R-squared & 0.086599 & S.D. dependent var & 0.04425 \\
S.E. of regression & 11.6386 & F-statistic & 0.350028 \\
Sum squared resid & 10.8524 & Prob(F-statistic) & 0.009118 \\
Durbin-Watson stat & 1.840302 & & \\
\hline
\end{tabular}

Table 3a indicates that there is positive and significant relationship between audit committee and return on equity. T-stats show that null hypothesis should reject. From above table H3 should accepted. Findings of this paper is consistent with previous literature (Yasser, et al., 2011). In majority of firms audit committee is being occupied by nonexecutive members and it has positive influence on performance of firm. These results have support with previous literature (Klein A, 1998; Roe M, 2002). Results also show that there is weak significant relationship between CEO duality and return on equity. So H1 should accept. Durbin Watson stats show that there is some positive auto correlation between the variables and probability of f-stats show that model is significant.

Table 3b Regression: PM as Dependent Variable

\begin{tabular}{lrcrr}
\hline Variable & Coefficient & Std. Error & t-Statistic & Prob. \\
\hline C & -0.03304 & 0.155216 & -0.21284 & 0.0337 \\
ACOM & 0.1698 & 0.136572 & 1.643301 & 0.0289 \\
CEO_DUALITY & -0.0624 & 0.088157 & -2.07081 & 0.0443 \\
R-squared & 0.079754 & Mean dependent var & & 0.116788 \\
Adjusted R-squared & 0.069711 & S.D. dependent var & 0.179141 \\
S.E. of regression & 0.180667 & F-statistic & 0.823329 \\
Sum squared resid & 0.620174 & Prob(F-statistic) & 0.004032 \\
Durbin-Watson stat & 1.641612 & & & \\
\hline
\end{tabular}

Table $3 \mathrm{~b}$ show that there is no relationship between PM and CEO duality and it is significant at $5 \%$ level of significance. These results have support with previous literature (Yasser, et al., 2011). So H2 should be rejected. Audit committee and profit margin has strong significant relationship with each other. Because of non executive members of audit committee, the performance of firm increases and in literature many studies support this argument that audit committee has strong significant relationship with profit margin (Klein, 1998; Muhammad Aves Arshad, et al., 2011; Yasser, et al., 2011).

Results of R-square in table $3 a$, b show that about 7-9\% change in performance of the firm is due to these variables and remaining change is due to unexplained variables.

\section{Conclusion}

This study is done on oil and listed firms of Pakistan and economic model is used. From 12 listed firms only 11 listed firms have been selected for analysis. The findings of this paper show that there is weak significant relationship between ROE and CEO duality. There is positive and significant relationship between ROE and audit committee. There is no relationship between the profit margin and CEO duality. Results also conclude that audit committee and profit margin has strong significant positive relationship with each other.

\section{References}

Abbott, L. J., \& Parker, S. (2000). Auditor selection and audit committee characteristics. Auditing: A Journal of Practice \& Theory, 47(2), 47-66.

Adenikinju, O., \& Ayorinde, F. (2001). Ownership structure, corporate governance and corporate performance: The case of Nigerian quoted companies. AERC biannual research workshop. Nairobi, Kenya.

Anderson, R., Mansi, S., \& Reeb, D. (2004). Board characteristics, accounting report integrity and the cost of debt. Journal of accounting and economics, 37, 315-342.

Arslan, M. \& Zaman, R., 2014. Unemployment and Its Determinants:A Study of Pakistan Economy (19992010). Journal of Economics and Sustainable Development, 5(13), pp. 20-24.

Bhagat, S., \& Black, B. (2002). The non-correlation between board independence and long- term firm performance 231-274. Journal of corporation law, 37.

Black BS, Tang H, \& Kim W. (2003). Does corporate governance affect firm value? Evidence from Korea. 237. 
Stanford Law School.

Cho, M. (1998). Ownership structure, investment and the corporate value: an empirical analysis. Journal of Finance and Economics, 47, 103-121.

Collis, J., \& Hussey. (2003). Business Research., New York

Demsetz, H., \& Villalonga, B. (2001). Ownership structure and corporate performance. Journal of corporate finance, 7, 209-233.

Donaldson, \& Davis. (1991). Toward a Stewardship Theory of Management. Acedmy of management Review, 22(1), 20-47.

Finance Committee on Corporate Governance (1999).

Gompers, P., Ishii, J., \& Metrick, A. (2003). Corporate Governance and Equity Prices. Quarterly Journal of Economics, 118(1), 107-155.

Goswami, O. (2002). Corporate Governance in India," Taking Action against Corruption in Asia and the Pacific. Asian development Bank, 85-106.

James, A., Brickley, a, J. L. C. h., \& Gregg, J. (1997). Leadership structure: Separating the CEO and Chairman of the Board. Journal of Corporate Finance, 3, 189-220.

Jensen, M. (1993). The Modern Industrial Revolution, Exit, and the Failure of Internal Control Systems. Journal of Finance, 48, 831-880.

Khanna M, \& D, L. (1999). EPA's Voluntary 33/50 Program: Impact on Toxic Releases and Economic Performance of Firms. J. Environ. Econ. Management, 37(1), 1-25.

Khanna M, Wilma RQ, \& Dora. (1998). Toxics Release Information: A Policy Tool for Environmental Protection. J. Environ. Econ. Mgt, 36, 243-266.

Klappe, L., \& Inessa, L. Corporate Governance, Investor Protection and Performance in Emerging Markets. 303979. Social Science Research Network.

Klein, A. (1998). Firm performance and board committee structure. Journal of law and economics, 41, 275-303.

Klein A. (1998). Firm performance and board committee structure,. Journal of law Economics, 41, 275-303.

Mallin, C. (2007). Corporate Governance. New York.

Morck, R., Shleifer, A., \& Vishny, R. (1988). Management ownership and market valuation: An empirical analysis. Journal of Finance, 20, 293-315.

Muhammad Aves Arshad, Rana Amir Satar, Mudassar Hussain, \& Mohammad Akram Naseem. (2011). Effect of Audit on Profitability: A Study of Cement Listed Firms, Pakistan. Global Journal of Management and Business Research, 11(9). NYSE. from http://www.nyse.com/

Pankaj, J. (1996). Managing credit for the rural poor: Lessons from the grameen bank. world development, 24(1), 79-89.

Roe M. (2002). Some Differences in Company Structure in Germany, Japan and the United States. Yale Law Journal, 102(7), 1927-2003.

SECP. (2012). Code of Corporate Governance. 1-42.

Shaheen, R., \& Nishat, D. M. (2004). Corporate Governance and Firm Performance- An Exploratory Analysis. Institute of Business Administration-IBA. Karachi.

Singh A, Singh A, \& B, W. (2002). Corporate Governance,Competition, the New International Financial Architecture and Larger Corporations in Emerging Markets. 250. ESRC Centre for Business Research, University of Cambridge. Uk.

Welman, C., Kruger, F., \& Mitchel, B. (2005). Research Methodology Oxford University Press (Vol. 3). Cape Town.

Wild, J. J. (1996). The Audit Committee and Earnings Quality. Journal of Accounting, Auditing \& Finance, 11, 247-276.

Yasser, Q. R., Entebang, H., \& Mansor, S. A. (2011). Corporate governance and firm performance in Pakistan: The case of Karachi Stock Exchange (KSE)-30. Journal of Economics and International Finance, 3(8), 842-491.

Arslan, M. \& Zaman, R., 2014. Unemployment and Its Determinants:A Study of Pakistan Economy (19992010). Journal of Economics and Sustainable Development, 5(13), pp. 20-24.

Zaman, R., Arslan, M. \& Sohail, M., 2014. The Impact of Monetary Policy on Financial Performance: Evidence from Banking Sector of Pakistan. Journal of Basic and Applied Scientific Research, 4(8), pp. 119-124. 
The IISTE is a pioneer in the Open-Access hosting service and academic event management. The aim of the firm is Accelerating Global Knowledge Sharing.

More information about the firm can be found on the homepage:

http://www.iiste.org

\section{CALL FOR JOURNAL PAPERS}

There are more than 30 peer-reviewed academic journals hosted under the hosting platform.

Prospective authors of journals can find the submission instruction on the following page: http://www.iiste.org/journals/ All the journals articles are available online to the readers all over the world without financial, legal, or technical barriers other than those inseparable from gaining access to the internet itself. Paper version of the journals is also available upon request of readers and authors.

\section{MORE RESOURCES}

Book publication information: http://www.iiste.org/book/

\section{IISTE Knowledge Sharing Partners}

EBSCO, Index Copernicus, Ulrich's Periodicals Directory, JournalTOCS, PKP Open Archives Harvester, Bielefeld Academic Search Engine, Elektronische Zeitschriftenbibliothek EZB, Open J-Gate, OCLC WorldCat, Universe Digtial Library, NewJour, Google Scholar

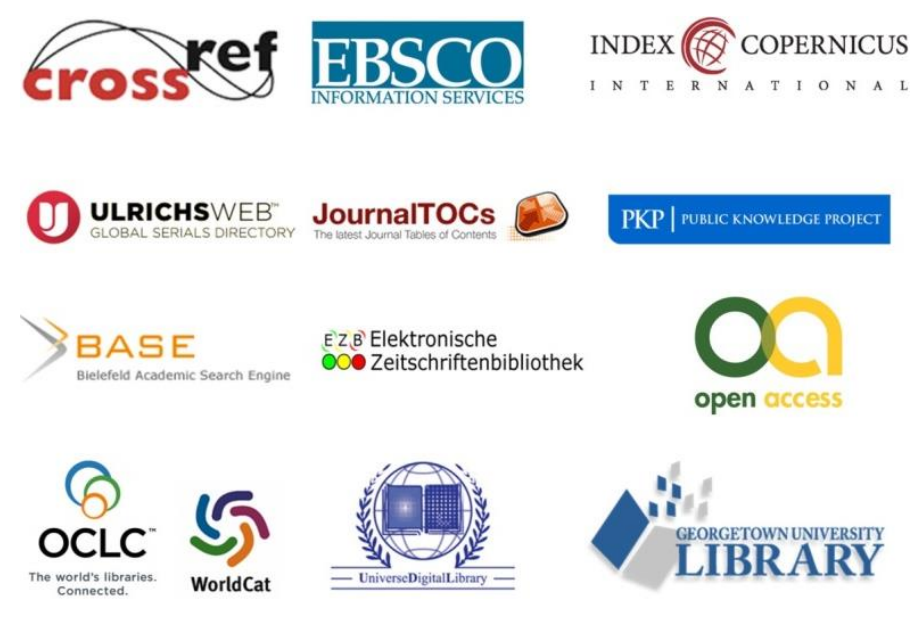

